\title{
"We act like girls and we don't act like men": Ethnicity and local language change in a Philadelphia high school
}

\author{
S U Z A N N E E A N S W A G N E R \\ Department of Linguistics and Languages A-632 Wells Hall, \\ Michigan State University East Lansing, MI 48824, USA \\ wagnersu@msu.edu
}

\section{A B S T R A C T}

How is ethnicity indexed linguistically in a speech community in which immigrant L2s have typically not been spoken for three or more generations? Drawing on recordings and ethnographic observations of eighteen white high school girls in south Philadelphia, speakers of Irish descent are shown to differentiate themselves from speakers of Italian descent through their use of (ay0), that is, Canadian Raising. (ay0) is an ongoing sound change in Philadelphia and is remarkable for being a rare example of a male-led change. Irish girls exploit more male-like, backed, and raised variants as a resource for indexing their ethnic identity, which is associated locally with stereotypically masculine characteristics such as toughness. The symbolic reflection of ethnic affiliation through this subtle linguistic device makes use of both local and supralocal social meanings. (Ethnicity, adolescence, Philadelphia, Irish, Canadian Raising, gender, sound change, language, and identity)*

\section{N T R O D U C T I O N}

The ethnic distribution of English sociolinguistic variables has been studied in large American cities since the 1960s (see e.g. Labov 1966/2006; Labov, Cohen, Robins, \& Lewis 1968; Shuy, Wolfram, \& Riley 1968; Laferriere 1979). Relatively few such studies, however, have made white, European-Americans their primary focus. Using sociophonetic and ethnographic data collected in Philadelphia, this study contributes to an understanding of why sociolinguistic differences may sometimes be detected between long-established European-American immigrant groups. Irish- and Italian-American adolescents are shown to exhibit a difference in their realization of a local sound change: the centralization of the nucleus of /ai/ before voiceless consonants, henceforth (ay0). ${ }^{1}$ Following the approach of Benor (2010) and others working within Eckert's (2005) "third wave" sociolinguistic framework, the article demonstrates that the (ay0) variable is an indexically rich resource for signaling not only speaker ethnicity, but multiple social meanings, especially within the adolescent lifestage. Although the study focuses only on 
females, it interrogates the construction of gender (masculinity, femininity) within females. The study shows how ethnic differences can locally index gender, and accomplishes this through an exploration of the "toughness" meaning of centralized (ay0).

It is important to note that centralization of (ay0) is not unique to the Irish and Italians in Philadelphia: it is a community-wide process among all white speakers in the city (Labov 2001). Until recently, sociolinguistic differences across ethnic groups in monolingual speech communities have been most prominently attributed to the effects of social segregation and social network, where variation across ethnic groups reflects the diffusion of a linguistic change from group to group over time (e.g. McCafferty 1998; Boberg 2004). Yet Philadelphia has been home to IrishAmericans and Italian-Americans for over a hundred years (Hershberg 1981), where they have lived in fairly close proximity, and a previous study found almost no linguistic differences between them (Labov 2001). In seeking to account for Irish and Italians' differential employment of (ay0), this article turns to a more agentive view of ethnolinguistic difference, in which speakers participate in language changes or employ stable features "not simply to reflect or reassert their particular pre-ordained place on the social map but to make ideological moves" (Eckert 2008a:464).

Fought $(1999,2003)$ takes the same approach, demonstrating that Chicano participation in Anglo-led (uw)-fronting ${ }^{2}$ in California is more than an epiphenomenon of speakers' exposure to the Anglo change. Participation depends on a complex array of factors including gang membership and community-specific expectations of gendered behavior. The continuum of (uw)-fronting thus does not perfectly reflect a continuum running from ethnic Chicano to ethnic Anglo identity, but encompasses a diverse array of speakers using (uw) for diverse social purposes. Likewise, in a study of ethnic groups in Toronto, Hoffman \& Walker (2010:59) summarize:

the speech community makes available a pool of linguistic features which are associated with (or come to be associated with) particular social distinctions and values.... Whether these features are already extant or are introduced into the pool through first-generation immigrants, speakers adopt and use these features strategically in ethnolinguistic variation.

The present article shows that the high school is a particularly good locus for exploring the "strategic" construction of linguistic correlates of ethnicity. This is especially the case, as pointed out above, in monolingual white speech communities where features derived from immigrants' home languages are (almost) no longer discernible. Indeed, although ethnolinguistic differences typically attenuate over the generations, age grading (Cheshire 2006; Wagner 2012a) may play a role in preserving them. In the present study, therefore, ethnicity is examined from the perspective of a single age group: adolescents aged sixteen to eighteen in their junior or senior year of high school. High school students are heavily engaged in the 
construction and maintenance of social oppositions (Eckert 1989). Perceived differences between the Irish- and Italian-American communities in Philadelphia today are relatively minimal, ${ }^{3}$ but they are magnified in the high school context and can be recruited for peer-group boundary creation and other meaning-making. The Irish and Italian categories in the high school described here reflect adolescent communities of practice (Lave \& Wenger 1991; Wenger 1998) that are rooted in - but not isomorphic with - opposing local norms of gender and social class behavior. In keeping with the third wave approach just outlined, I argue that for these speakers, raised and/or backed (ay0) is not directly associated with membership in an ethnic category. Instead, it indirectly indexes (Ochs 1992) a number of more general qualities such as "toughness" that happen to be more positively valued in the Irish community than the Italian community.

\section{THE S T U D Y}

\section{Sacred Heart High School}

The linguistic and ethnographic data for this study were collected during two threemonth long periods of participant observation in 2005 and 2006. The observation site was "Sacred Heart High School,"4 an urban, co-educational Catholic school (grades seven through twelve) in South Philadelphia. ${ }^{5}$ This area is popularly associated with white, working-class culture (Dubin 1996), despite its ethnic diversity (53\% white, $34 \%$ black, 9\% Asian) and a median household income that is only slightly below that of the entire city $(\sim \$ 31,000$ Philadelphia, $\sim \$ 27,000$ South Philadelphia). The school itself is located in a majority white, majority Italian ancestry neighborhood, but draws students from parochial grade schools across South Philadelphia.

White South Philadelphians are largely of Irish or Italian descent, with the highest concentration of people of self-identified Irish ancestry (43\% Irish) in the eastern Pennsport district known as "Second Street," a neighborhood that is of central importance in this article. The next highest concentration of Irish ancestry residents is in the western "Thirtieth Street" district (26\% Irish), bookending those of Italian ancestry in the middle neighborhoods (57\% Italian), with the exception of some narrowly defined districts around 5th to 8th streets that are home to people of various other ethnicities including African-Americans and Asians. People of Italian ancestry are also highly concentrated (82\% Italian) in the southern neighborhood of Packer Park. This dense residential aggregate of Italian-Americans in South Philadelphia's highest-income neighborhood has contributed to the conviction among Sacred Heart students (discussed below) that the local Italian community is wealthier than the Irish community.

All of the participants in the Sacred Heart project were white. The whiteness of the school population (at that time, 79\% according to internal school records) was important for linguistic reasons. Philadelphia's white community had been 
extensively studied by sociolinguists since the 1970s (see Labov 2001 and references therein) and this provided a detailed baseline for the main goal of the larger study from which the present article is derived: an analysis of the students' participation in community-wide sound changes as they aged (Wagner 2008, 2012b). Earlier studies in the city (Poplack 1978; Adamson \& Regan 1991; Henderson 1996) had also established that nonwhites generally do not participate in local mainstream white linguistic changes, even where ethnic communities are fairly well integrated. It became clear to me very rapidly, however, that the white Sacred Heart students did not view themselves as ethnically homogenous, and this provided the impetus for additionally exploring linguistic markers of ethnic affiliation.

Following the methodology employed by Eckert (1989), I spent most of every day in the school - in the hallways, the cafeteria, and the school offices, and very occasionally in a classroom. The participants represent a convenience sample, located through the "friend of a friend" technique (J. Milroy \& L. Milroy 1985; L. Milroy 2002). I conducted digitally audiorecorded sociolinguistic interviews with sixty-six young women, ${ }^{6}$ of whom forty were recorded in both observation periods. The majority of participants were first interviewed in grade twelve, their senior year, aged seventeen to eighteen; others were first interviewed in their junior or sophomore year, aged sixteen to seventeen.

\section{The sample for phonetic analysis}

Previous studies of ethnolinguistic features have included variable realization of consonants (e.g. Dubois \& Horvath 1998; Rose 2006; Mendoza-Denton 2008), lexical items (De Fina 2007; Benor 2012), suprasegmental processes such as syllable-timing (Fought \& Fought 2002; Torgersen \& Szakay 2011), morphosyntax (Malan 1996; Green 2002; Cheshire \& Fox 2009) and discourse/pragmatics (Meyerhoff 1994; Stubbe 1998; Torgersen, Gabrielatos, Hoffmann, \& Fox 2011). The phonetic analysis in this article is limited to the vowel system, in the full acknowledgement that Irish and Italian ethnolinguistic variability is highly unlikely to be confined to these vocalic variables. ${ }^{7}$ Nonetheless, it is the vowel system that has received the most attention over the decades in the literature on the Philadelphia speech community mentioned above (Labov 2001; Conn \& Horesh 2002; Conn 2005; Fruehwald 2008; Wagner 2008; Labov, Baranowski, \& Dinkin 2010; Fruehwald \& MacKenzie 2011; Prichard \& Tamminga 2012), and that therefore provides the best community-level backdrop against which to compare the young people in this study.

Eighteen speakers were selected for their socioeconomic and ethnic characteristics (Table 1), and these are discussed in more detail below. For each of the eighteen speakers, their 2005 interviews were manually segmented in Praat 4.5.118 for stressed tokens of forty-seven vowel classes and allophones. The coding system of the Plotnik 8 program ${ }^{9}$ was used, which identifies twenty-five American English 
vowel classes (Labov 1994, 2001), thirteen classes of allophones before /1/, and nine classes of allophones before $/ \mathrm{r} /$. A minimum of ten tokens per main vowel class was aimed for (although in practice this was not always achieved, due to the brevity of some interviews), with no more than three tokens of any lexical item, for an average of 270 total tokens per speaker. ${ }^{10}$

TABLE 1. Panel for vowel analysis, eighteen speakers by socioeconomic status (SES) and ethnicity.

\begin{tabular}{llll}
\hline \hline Ethnicity & SES 1 & SES 2 & SES 3 \\
\hline Irish & Erin & Abby & Danielle \\
& Kerry & Joanna & Deirdra \\
& Melanie & Julia & Claire \\
Italian & Natalie & Hayley & Angela \\
& Courtney & Amanda & Lucia \\
& Becky & Emma & Chelsea \\
\hline \hline
\end{tabular}

The ethnic categories of "Irish" and "Italian" are described in more detail in the next section. A composite index of parents' education, caregivers' occupation, and residence value (Conn 2005; Wagner 2008) was used to allocate the informants to one of three socioeconomic status (SES) categories. SES 1 represents the lowest socioeconomic category, and SES 3 represents the highest. Categorizing minors by social class is a well-known problem in both sociology (see e.g. Hughes \& Perry-Jenkins 1996 for a review) and sociolinguistics (Eckert 2000; Fought 2003; Cameron 2005). Since minors are not yet fully engaged in the socioeconomic activity of their community, it is usual to classify them according to their parents' status, as I have done here. The educational and occupational background of вотн parents (if relevant) was incorporated into the index calculation. For concision, I present in Table 2 some examples of parental occupations cited by Sacred Heart students, to illustrate the three SES categories.

TABLE 2. Examples of Sacred Heart parents' occupations by SES.

\begin{tabular}{ll}
\hline \hline SES & Representative Sacred Heart parental occupations \\
\hline $1 \quad \begin{array}{c}\text { glazier, mailroom clerk, waitress, toll booth attendant, babysitter, cashier, office clerk, bus } \\
\text { driver, cook } \\
2\end{array}$ & $\begin{array}{c}\text { longshoreman, typesetter, sales clerk, dental assistant, teacher's aide, secretary, real estate agent, } \\
\text { bookkeeper, loan processor } \\
\text { police officer, legal assistant, teacher, convenience store owner, accountant, building contractor, } \\
\text { architect }\end{array}$ \\
\hline \hline
\end{tabular}

E T H N I I T Y, O R “W HERE Y O U R E F R M ”

The ethnic categories assigned to the speakers in Table 1 were based on a combination of self-identification and my own judgment. So many students had 
mentioned Irish or Italian affiliation in their 2005 interviews that in the 2006 followup interviews I gave participants a written survey to complete. It included questions about ethnicity and how the participants would usually describe themselves to others. Ethnicities mentioned by students in the survey included Irish, Italian, German, Polish, English, Armenian, and Chinese. In practice, however, Sacred Heart girls tended to align themselves with one of the two dominant ethnic groups: Irish or Italian. The Irish and Italian designations in Table 1 reflect the written responses provided by the eighteen participants. For the few speakers who described themselves using hyphenated ethnic terms (e.g. Irish-Polish), I coded them as Irish or Italian based on the dominant ethnicity of their neighborhood, information from their interviews, and my own observations of their friendship networks. In conversations, all of the white students I spoke to identified themselves as either Irish and/or Italian, and this binary ethnic opposition was by far the most dominant (white) social segregator in the school.

Across the United States, formerly separate European immigrant ethnic groups have increasingly come to participate in what Hall-Lew (2010:460) refers to as "the powerful... construction of whiteness," thereby reducing or eliminating withinwhite ethnic difference. Yet at Sacred Heart the Irish and the Italians continued to enjoy highly contrastive visibility. The maintenance of Irish and Italian ethnic identity came at the expense of other ethnicities in a local process of erasure (Irvine \& Gal 2000). Students appeared to be collectively participating in an "imagined homogenization" (Gal \& Irvine 1995:974) of European-Americans at the Sacred Heart as exclusively "Irish" or "Italian." I saw this homogenization process at work when I conducted a controlled discussion of Sacred Heart peer categories in 2006. A group of girls, who had been seniors in the first round of fieldwork and who were still close friends, completed a collaborative "pile-sort task" (Matthews 2006). Photographs of every member of their senior class, copied from their senior yearbook, were placed in a pile on the table. I asked the girls to sort the photographs into groups using any criteria they chose. They immediately sorted the nonwhite students into two groups ("Blacks" and "Asians") and removed them from further consideration. By the end of the task, nine of the twenty groups - and the majority of the students - had been defined by race, neighborhood, or grade school: for white students, all instantiations of Irish and Italian ethnicity. Conversations with other students demonstrate that these criteria were not particular to the group engaged in the pile-sort task. In (1), Courtney and Danielle spontaneously raised the subject of their own ethnicities.

(1) Courtney: You're in the Irish part. I'm in the Italian part [...]

Danielle: Yeah, we- In school you go by where you're from.

The frequently invoked concept of "where you're from" did not concern ancestral countries: none of the girls were "from" Ireland or Italy. Rather, membership in one of the two opposed ethnic categories was perceived as and legitimized by a 
combination of biological heritage, residence in an ethnic neighborhood, attendance at an Irish- or Italian-dominant grade school, past affiliation with a local street corner or park, and present social network. In (2) two Italian students contrasted peers from traditionally Irish neighborhoods (Second Street and Thirtieth Street) with peers from Italian neighborhoods.

(2) Monica: [Eighth grade], that's when we started like knowing like people from the other side of Broad [Street] [i.e. other Italians].... But like the Second Streeters and all and the Thirtieth Streeters [i.e. Irish], we-

Natalie: Yeah, we don't like know them and we don't really talk to them 'cause they're not- they're different from us. They're not like us.

Monica: Yeah, they clique together.

Natalie: $\quad$ Yeah. Different types of people. There's definitely an Italian-Irish split, I think.

Neighborhood-based ethnic ties constrained the establishment of new friendships when students started attending Sacred Heart. It is noteworthy that Monica, in (2), implies that she had no friends beyond her Italian social network prior to eighth grade - that is, for her entire first academic year at Sacred Heart. Because ethnic group membership at Sacred Heart could be defined along several parameters, one could be more or less Irish, or more or less Italian. The school continuum ranged from the most iconically Irish students ("Second Streeters") to the most iconically Italian ("princesses"), ${ }^{11}$ with everyone else in between, or excluded altogether. ${ }^{12}$ No jock-burnout continuum emerged of the kind described by Eckert (1989), or indeed any single set of "populars" (Moore 2003). In (3), jocks and burnouts were explicitly rejected.

(3) SW: $\quad$... people who are really school-oriented versus people who are really nonschoolHayley: No, we really break down by neighborhoods.

Julia: $\quad$ Exactly. [general agreement, yeses, etc.] And corners. Corners and neighborhoods.

Melissa: Corners and parishes, like old [grade] schools.

Opinions differed regarding the importance of neighborhood for ethnic membership. Danielle, for example, was from an Irish family and grew up on Second Street, but she had attended an Italian grade school outside her neighborhood and so had many Italian friends. Nonetheless, in her view, neighborhood residence was a primary determinant of category membership, and she made a claim to Irish ethnic identity on this basis. "If Second Street ever gets into a fight," she told me, "even though... I don't even stay ${ }^{13}$ there, I'd have to be part of Second Street side." But her claim to Irish membership wasn't ratified by other students. In the pile-sort task she was described as "someone who's really popular" but "not popular on Second Street," and thus "someone who doesn't really belong there." In other words, popular kids existed, but there were distinct groups of IRISH popular kids and ItALIAN popular kids. Irish popular kids were usually those whose social lives were heavily intertwined with multigenerational networks on Second Street, 
and who spent a lot of time there in its parks and on its corners. Danielle wasn't one of these kids, so the sorters didn't know what to do with her. Their additional refusal to group her with the Italian popular crowd, even though the Italian populars were her friends, underlines the possibility that popularity at Sacred Heart was not independent of the Irish-Italian ethnicity continuum.

Whatever the disagreements over the classification of individuals into ethnic groups, white students at Sacred Heart were unified in their strong foregrounding of these social categories. Since we might reasonably expect to find linguistic differentiation where we find social differentiation, the vocalic systems of the nine Irish and nine Italian students in the present sample were compared.

\section{R E S U L T S}

Labov's 1970s survey of white Philadelphia English found that ethnicity (Italian, Irish, Jewish, German, WASP) ${ }^{14}$ generally did not co-vary with vowel production (Labov 2001:257). Only in the fronting of (uw) (as in shoe, boot) and (ow) (as in go, boat) was there a clear effect of ethnicity, where Italians lagged approximately 100$200 \mathrm{~Hz}$ behind other ethnic groups. Substrate influence from Italian was not an explanatory factor (Labov 2001:258-59). The data were collected at a time when Irish-Italian social tension and segregation were still evident. In his popular account of the history of South Philadelphia, former journalist Murray Dubin quotes a Polish-American who was born in South Philadelphia in the 1940s and who recalled of his youth.

Italians... [didn't] date Two-Streeters. It was a pretty rough neighborhood in those days, all Polish and Irish. Going south, you start running into guys you knew, but it was a different territory, and you had to have good reasons for being down there. They didn't like you dating girls in their neighborhood, but they tolerated it. (Dubin 1996:188)

In (4), Italian-American Veronica describes Irish-Italian relations when her father was young, perhaps a decade after Labov's project.

(4) Veronica: Yeah, the Italian people don't like the Second Streeters. And the Second Streeters are all the people who are Irish. A lot of Irish people live on Second Street. And a lot of Italian people live from Sixth Street over. And so you got the Irish people on one side and the Italian people on one side. And they always used to battle. Like, they always used to hate each other. Now it's just starting to calm down since we got older. And like- some- like an Italian boy might like an Irish girl so- I mean, it's calming down but you can still see a little rivalry.

SW: $\quad$ So you mean it's calming down since you all got to high school, or it's calming down generally over the generations?

Veronica: Over generations. Like my dad used to tell me when he lived in- on Sixth Street where I always lived that you weren't allowed to pass Second Street because of the Irish people. 


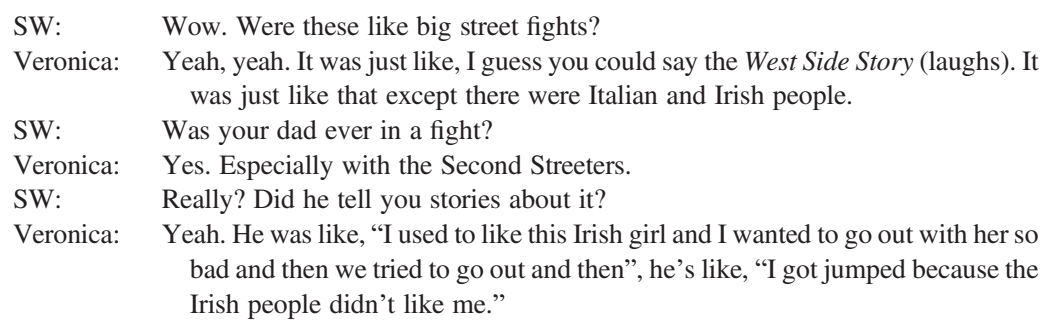

By the time the Sacred Heart participants were in high school, the ethnic tension between Italians and Irish had become more moderate. Veronica told me that the tension had "come down" since her father's youth. The retarding effect of Italian ethnicity on (ow) and (uw) had apparently also lessened as the two groups became more integrated. In the Sacred Heart data, Italian lagging was evident only for the checked allophone of (ow), as in, for example, phone, most, hose (Wagner 2008:189-90). It appears that this particular correlation with ethnicity has waned since the 1970s. No significant ethnic effects were found for any of the other vowels, with the exception of (ay0).

(ay0)

Significant effects of ethnicity and social class emerged in a series of t-test comparisons of vowel means. Table 3 displays the mean F1 and F2 for speakers grouped by socioeconomic status and ethnicity.

TABLE 3. Normalized means of (ay0) for eighteen speakers by SES and ethnicity.

\begin{tabular}{lccc}
\hline \hline Variable & $\mathrm{F} 1$ (ay0) $\mathrm{Hz}$ & $\mathrm{F} 2($ ay0) $\mathrm{Hz}$ & $\mathrm{N}$ \\
\hline Socioeconomic status & & & \\
SES 1 & 621 & 1413 & 77 \\
SES 2 + SES 3 & $* * 647$ & 1432 & 196 \\
Ethnicity & & & 138 \\
Irish & 644 & $* 1450$ & 135 \\
Italian & 635 & & $\mathbf{2 7 3}$ \\
Total N & & & \\
\hline \hline
\end{tabular}

** $p \leq 0.001 ; * p \leq 0.05$

The results in Table 3 show that there is an effect of social class on the height of the (ay0) nucleus, with speakers in SES 1, the lowest social class group, exhibiting more raised nuclei on average than their peers in SES 2 and SES 3. This is unsurprising: the raising of the nucleus of (ay0) was identified as a "new and vigorous change" in the 1970s (Labov 2001) led by the working class, and the nucleus has continued to raise rapidly in the decades since (Conn 2005; Labov 2011), with the working class still in the lead. 
No effect of ethnicity on the front-back dimension of (ay0) had previously been identified, however. Yet it can be seen in Table 3 that on average the nine Irish teenagers are significantly more advanced than the nine Italians with an F2 value that is on average approximately $50 \mathrm{~Hz}$ backer than the Italian F2 value. Figure 1 displays, for each of the eighteen speakers, the mean F1 and F2 of (ay0) and of (ayV), which is the nucleus of /ai/ before voiced consonants (e.g. bide, time). The raising of (ay0) in the F1 dimension is apparent. The normalized means for the Italian girls' (ay0) cluster within the black-outlined oval to the left, while the means for the Irish girls cluster within the gray-outlined oval to the right. Even though, at the individual level, the speaker with the frontest mean (ay0) is an Irish girl, Melanie, and the backest nuclei were produced by two Italian girls, Becky and Courtney, the general trend is for Irish girls to produce (ay) further back when it is followed by a voiceless consonant rather than (ay) before voiced consonants. In contrast, Italian girls produce (ay) before voiceless consonants in a fronter position rather than (ay) before voiced consonants.

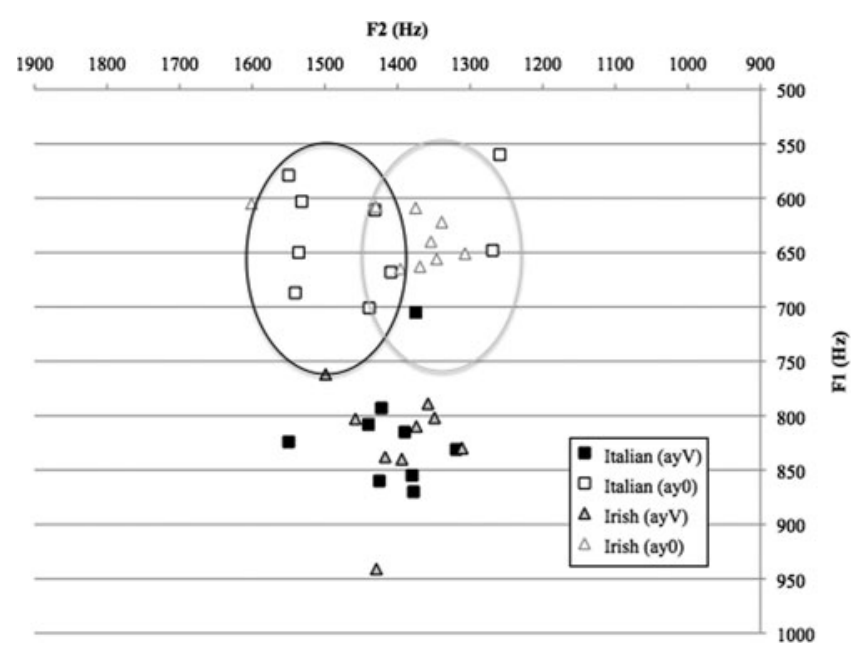

FIGURE 1. Mean (ay0) and (ayV) values for eighteen speakers by ethnicity.

In an analysis of the unnormalized (ay0) means by individual, all but one of the speakers (Natalie), exhibited (ay0) nuclei that were significantly higher than their (ayV) nuclei $(p<0.05)$. Thus all speakers except Natalie ${ }^{15}$ display the allophonic distribution of (ayV) and (ay0) that we would expect for Philadelphians their age. For the front-back dimension each individual's unnormalized F2 of (ayV) was compared with her normalized F2 for (ay0) in a t-test. Speakers whose (ayV) and (ay0) F2 values were significantly different (i.e. their mean (ay0) was significantly fronter or backer than $(\mathrm{ayV}))$ are indicated in Table 4 with asterisks. 
TABLE 4. Unnormalized mean values of (ayV) and (ay0) by individual speaker (Ir = Irish; It = Italian; $1,2,3=$ SES 1, 2, 3 respectively).

\begin{tabular}{|c|c|c|c|c|}
\hline Speaker & Social background & Mean F2 (ayV) & Mean F2 (ay0) & Mean difference \\
\hline Erin & Ir, 1 & 1429 & 1354 & -75 \\
\hline Melanie & Ir, 1 & 1499 & 1601 & $* * 102$ \\
\hline Natalie & It, 1 & 1375 & 1409 & 34 \\
\hline Kerry & Ir, 1 & 1311 & 1375 & 64 \\
\hline Julia & Ir, 2 & 1420 & 1339 & -81 \\
\hline Abby & $\mathrm{Ir}, 2$ & 1374 & 1396 & 22 \\
\hline Claire & Ir, 3 & 1349 & 1346 & -3 \\
\hline Danielle & $\mathrm{Ir}, 3$ & 1394 & 1369 & -25 \\
\hline Deirdra & Ir, 3 & 1358 & 1307 & -51 \\
\hline Becky & It, 1 & 1380 & 1259 & $* *-121$ \\
\hline Courtney & It, 1 & 1319 & 1269 & -50 \\
\hline Amanda & It, 2 & 1378 & 1439 & 61 \\
\hline Emma & It, 2 & 1550 & 1550 & 0 \\
\hline Hayley & It, 2 & 1390 & 1431 & 41 \\
\hline Joanna & It, 2 & 1458 & 1430 & -28 \\
\hline Angela & It, 3 & 1425 & 1536 & 111 \\
\hline Chelsea & It, 3 & 1441 & 1533 & $* * 91$ \\
\hline Lucia & It, 3 & 1422 & 1541 & $* 119$ \\
\hline
\end{tabular}

$* * p<0.01 ; * p<0.05$; all others are not significant.

Most speakers show no significant difference in F2 between their nuclei of (ay0) and (ayV); the exceptions are Melanie, Lucia, and Chelsea, whose (ay0) is significantly fronter than their (ayV), and Becky, whose (ay0) is significantly backer. Overall, however, Irish girls' F2 of (ay0) is on average $75 \mathrm{~Hz}$ backer than their mean F2 of (ayV), and Italian girls' (ay0) is on average $287 \mathrm{~Hz}$ fronter than their (ayV), as derived from the individual normalized mean differences in the righthand column of Table 4 .

\section{I S C U S S I O N}

The association of more backed (ay0) nuclei with Irish girls and more central or fronted (ay0) nuclei with Italian girls is subtle, but it is reflective of the symbolic values attached to the (ay0) front-back dimension in the wider community. I argue in this section that in Philadelphia, (ay0) indexes men and the working class, and that the teenage girls in this study are making use of (ay0)'s indexical meanings for their own local, age-appropriate stylistic purposes.

\section{Previous studies: Production and perception of (ay0)}

In the 1970s, the raising of the nucleus of (ay0) in Philadelphia was being led by the working class, as mentioned in the previous section. Evidence that this lead has 
been maintained has been provided in follow-up studies, such as Conn's (2005) trend replication of Labov's 1970s apparent time survey of the city. Conn's study also revealed that a slow (ay0) backing change was in progress, and that this backing was only evident in the working classes (Conn 2005:101). Although no sex effects have been demonstrated for the backing change, both Labov (2001) and Conn (2005) report that men are leading in the raising of the nucleus. This is an extraordinary finding, given that women have repeatedly been shown to lead linguistic change (Labov 1990). Men and the working class are therefore implicated as the vanguard in changes in the phonetic position of (ay0).

Labov (2001:203-4) described (ay0) in the 1970s as a "change from below," in the sense of being below the level of public awareness. Noone in that study commented explicitly on (ay0), as they often did for the older sound changes such as the nearly completed tensing of (aeh). ${ }^{16}$ Conn likewise did not report any overt mention of (ay0) among his participants in their discussions of typical Philadelphia speech. However, in the 1970s subjective reaction tests, people consistently downgraded advanced variants of (ay0), a typical reaction to an ongoing change from below that suggests some sensitivity to the change. In the 2000s, Conn's participants went a step further, downgrading only the advanced variants of (ay0) produced by a female speaker, and UPGRADING advanced variants produced by a male speaker. The male-produced advanced (ay0) variants were evaluated as tougher and more masculine than the conservative variants. It is possible that if Labov had played (ay0) samples produced by both male and female speakers that he would have gotten similar results, and this hypothesis is supported by some of the off-the-cuff comments noted by the fieldworker, Ann Bower (Labov 2001:203). In South Philadelphia, an Italian informant described the advanced variants as "Two-streets! sounds like the Irish on Second Street." In an Irish neighborhood, a young woman said that the advanced variants sounded "like tough kids." Hindle's (1980) study of the speech of a single subject, Carol Meyers, over the course of a single day, provided data on (ay0)'s sensitivity to social situations. Carol produced more advanced variants when she was at work, and less advanced variants when playing bridge at home with her girlfriends. In other words, we can suppose that more advanced, male-like variants were appropriate in the tougher, male-dominated world of work, while more conservative, female-like variants were appropriate for the bridge game.

Centralized variants of (ay0) thus appear to have covert prestige (Trudgill 1972) in Philadelphia. Centralization is led by men and the working class, and this is to some extent perceived by members of the speech community, who assign these traits to advanced speakers and evaluate them positively if speakers embody those social characteristics. Yet as Ochs (1992:341) has argued for gender categories, social meanings rarely map straightforwardly or statically on to any macrosocial categories such as "male" and "working-class." Rather, these meanings are constantly available for activation (or not) by speakers and listeners in their construction and deconstruction of linguistic style. By using advanced variants of 
(ay0), speakers are not necessarily making the claim that they are members of the working class, or that they are men; nor are they even positioning themselves as "like men" or "like the working class." As Eckert (2008a:455) points out, "women (and men) are not saying 'I'm a woman' when they use a 'female-led' change, nor are they saying 'I'm not a woman' when they do not." Under this view, the relationship between a sociolinguistic variable and the demographic categories in which it is most frequently produced is an indirect and fluid one. Variables accrue interrelated meanings (an "indexical field" in Eckert's terms) not only at the macrolevel, but also at the local, microsocial level; existing meanings are reinforced and new meanings acquired in the moment of interaction. This might especially be the case for changes in progress, whose indexical fields may be "less well-defined" than those for well-established variables such as (ing), $(-t,-d)$ deletion, (dh), and hyper-articulation of $(\mathrm{t})$, but "leave more room for local interpretation" (Eckert 2008a:471).

In Philadelphia, as we have seen, advanced (ay0) variants were heard not only as male and working class, but as typical of Irish speakers from the iconic South Philadelphia neighborhood of Second Street. This suggests that (ay0) is best understood as available for interpretation at several levels of indexicality (Silverstein 2003). At a first-order level, it is heard by local listeners as indexing local Irish ethnicity; but it simultaneously activates second-order indexical meanings such as "working class" (for the Irish community in Philadelphia, both a historical and a contemporary association), which in turn activates third-order indexical meanings such as "male" and "tough." In the next section, I explore the indexical relationship between Second Street and toughness through my observations of and conversations with Sacred Heart students.

\section{Two-streets! Sounds like the Irish on Second Street}

Second Street —also known as "Two Street"-was more frequently mentioned at Sacred Heart than any other South Philadelphia neighborhood. In Gal \& Irvine's (1995:973) terms, it iconically represents the Irish community's "inherent nature," and was locally perceived as embodying the essence of Irishness. Melissa, for instance, expressed it this way:

(5) Melissa: If you say Second Street to somebody in Philly they're like, "Oh, Second Street." Like if you - You could say something like, "Oh, that's so Second Street!" and people would know exactly what you're talking about. [...] Second Street is always Irish. If you're Irish, you're probably from Second Street. If you look Irish or your name is Irish you probably are from Second Street.

No single locality was ever as strongly associated with the Italian community in any of the conversations I had with students. Natalie commented, "We're all Italian but we don't show it, like 'Oh, we're Italian.' Like the Irish people are so into that they're Irish." Her observation that the Irish in school "are so into that they're 
Irish" was confirmed by the girls' choice of AOL screen names. At the time, AOL was the service most commonly used by the girls who had an internet connection at home, and I used the AOL instant messenger service to contact them. For the thirtynine screen names I collected (Table 5), only two of the Italian girls opted to incorporate ethnic names like bella and bella ragazza 'beautiful girl.' Yet fully twelve of the seventeen Irish girls incorporated an ethnic marker, usually a variation on "Two Street."

TABLE 5. AOL screen names as markers of ethnic identity.

\begin{tabular}{lcccc}
\hline \hline Ethnicity & $\mathrm{N}$ & $\mathrm{N}$ ethnic names & \% ethnic names & Screen names \\
Irish & 17 & 12 & 71 & Irish, Twostreet, 2st \\
Italian & 14 & 2 & 14 & bella, bella ragazza \\
Other & 8 & - & - & - \\
Total & 39 & - & - & - \\
\hline \hline
\end{tabular}

A student who described herself as "from Second Street" or as a "Second Streeter" rather than "from Pennsport" (the municipal name for the wider neighborhood in which Second Street is located) or "from Third and Mifflin" (a street intersection in the neighborhood) was not only describing where she lived, nor simply claiming Irish ethnicity, but claiming allegiance to the most salient cultural practices of Second Street. Melissa's characterization of Second Street in (6) is representative of many other similar descriptions:

(6) Melissa: Second Street is like um where-you know, where the clubhouses are. Where the Mummers are, all that stuff. They're all down that way. And it's a big drinking area, and you know, nobody has a problem with underage drinking down there. And that's a whole group of people who hang out together. They all go to, you know, [parochial elementary school] or um what else [parochial elementary school]. And they're that kind of, you know-they're all friends. ... It's like you know, blue collar working class.

Melissa sketches Second Street with a few key features of what she typifies as its "blue collar" culture: dense social networks, drinking, and turning a blind eye to drinking laws. Melissa was a middle-class Italian, but the same features were described proudly by Second Streeters themselves. It was a place where everyone knew everyone else. Girls explained to me the concept of the "Second Street cousin," or child of an unrelated family friend. Second Street provided numerous places for people to interact with their neighbors: clubhouses of the many workingclass men's performance groups known as Mummers Clubs, a highly popular neighborhood basketball center, and, as I was told by everyone, "a bar on every corner."

These local perceptions of Second Street are crucial to interpreting the distribution of (ay0) in the Sacred Heart sample. Second Street is strongly locally associated with the same indexical meanings that listeners in previous studies assigned to 
advanced tokens of (ay0): Irish ethnicity, working class, but also maleness and toughness. As such, "Second Street" is itself at the center of an indexical field. "Second Street" indexes the local construction of Irishness. This in turn indexes a set of values and practices with related social connotations, in both local and nonlocal spheres. Local Irishness indexes drinking in corner bars, a practice that is traditionally associated both in Philadelphia and across the nation with working-class men. Local Irishness also indexes the Mummers Clubs, which are heavily maledominated and function as additional places to drink. As for sports, although participating in or watching sports was common to both sexes at the Second Street community sports center, it is still a traditionally male activity in the wider Philadelphian and national community. The dominant sport at the sports center, amateur basketball, was played by both sexes, but it is associated more generally in American culture with urban, working-class men. ${ }^{17}$

For young Irish women in the high school, sports in particular were used as a cultural shorthand for "typical" Irish characteristics. The exchange in (7) highlights the locally foregrounded intersection of Irish ethnicity and masculinity. Abby and Kaitlyn, both Irish girls, are talking about boys from a local all-male school who recently joined their class. They present the boys' reported speech as evidence that Irish girls' interest in sports is one of several indicators that they are independent, with appealingly male-like qualities. They explicitly contrast the laidback attitude of Irish girls with that of the "dagos,"18 who are prissy and helpless. Likewise, in (8), Irish-affiliated girls, Sarah and Melanie, unflatteringly characterize the most Italian of Italian girls as über-feminine "Italian princesses."

(7) Kaitlyn: Even like the boys that like came are like, "Irish girls are so much easier than like-"

Abby: $\quad$ Yeah. They know it's a lot easier. Cause we're so much more laidback. Like, we don't care.

Kaitlyn: Yeah. Like, they're like, "Youse are all easy-going." He's like, "The dagos, we have to be like, Oh my god, like you wanna do this, go here, you can't do this for yourself." He's like, "Youse, like, girls like sports and everything!"

Abby: Yeah! Or when we like- burp and stuff.

(8) Sarah: Well, sometimes like, you have the Italian princesses, they are dagos.

Melanie: The stuck-up ones who wear the too much lip liner, and put their-

Sarah: $\quad$ And all the gold jewelry and all the perfect bags and everything perfect.

Melanie: And their mothers go tanning and they look like they were in a toaster.

Italian girls were similarly dismissive of the Irish girls' behavior, sometimes explicitly characterizing it as masculine (see (8)). When I asked Natalie and her friend Monica (both Italians) about a street fight that had occurred outside the school that week, Natalie claimed not to know anything about it. Monica filled it in: it was a fight between Second Street and an Italian gang, and "the Second Street girls were in it too." Natalie responded indignantly in (9). 
(9) Natalie: See, like that, like that they wanted to fight. We would never really like-... We wouldn't act like that. [...] We just act like girls and we don't act like men and try to like fight or whatever all the time...

Natalie's comments reflect the prevailing ideology in the school that Italian girls were more feminine than Irish girls. My own observations also support this. Successful construction of ethnic identity at Sacred Heart was achieved through a process of bricolage (Hebdige 1984): the assembling of symbolic resources such as hairstyle, dress, and physical demeanor that in concert could be interpreted locally as constituting "Irish" or "Italian." Italian girls were likelier to have hair that was more artfully arranged and wear greater quantities of make-up and jewelry. Irish girls and Italian girls alike wore make-up, carried small reproduction designer purses and sported nail extensions, but Italian girls were more likely to do all of these things, while Irish girls might carry the purse and wear nail extensions, but eschew heavy make-up and wear their hair pulled back in a ponytail. Irish girls were more likely to tell me that they "didn't care" how they looked at school, with the implication often being that Second Street — and not school—was their primary arena for social display. Irish girls were also more likely than Italian girls to tell funny stories about their own physical clumsiness. The Irish girls themselves didn't necessarily display "toughness" in the sense of aggressiveness, but their subversion of some of the expected norms of female demeanor led to the perception within the school that they were "acting like men," and thus that they were "tough" and liked to fight. As Natalie's comment underscores, however, the local interpretation of symbolic resources occurs in the context of wider societal meanings. Acting like a Sacred Heart Irish girl can only be understood as "acting like men" in a Western society where clumsiness, for instance, is considered an undesirable trait in women. In a similar analysis, Eckert (2008a:548) describes the wearing of pastel-colored clothes by popular preppy girls in a California school as being locally associated with their peer group, but nonlocally associated ("culture-wide") with innocence: a characteristic that is also desirably associated in American culture with females. In other words, to indicate their position as nice girls (i.e. proper, well-behaved girls) in the local peer social order, preppy girls had not coincidentally selected pastels as one of the components of their style. It is also not coincidental, I would argue, that components of Irish girl style (or the proportion of their use) index masculinity at a societal level, while components of Italian girl style index femininity.

Eckert (2000) has also pointed out that language is an important component in adolescent stylistic bricolage. The (ay0) variable is an indexically rich resource available for this process, and the results of the sociophonetic analysis suggest that it is certainly recruited. Centralized — and especially backed-(ay0) is associated with Second Street girls such as Erin, who display a certain kind of male-like camaraderie with each other and with boys. Thus Second Street and (ay0) lie at the intersection in Sacred Heart of masculinity and Irish ethnicity: two social values 
that locally index "toughness," and this is reflected in the backed variants of (ay0) produced by Irish girls.

Centralized (ay0) was associated with toughness in another study, too: the Burnouts at Belten High produced the most advanced tokens of this vowel in general, and particularly when discussing their own nonconformist behavior, such as staying out all NIGHT, being HYPER (Eckert 1996). Gordon \& Heath (1998) went so far as to suggest that the association of men (or in the present case, stereotypical features of masculinity) with back-vowel changes might prove to be a sociolinguistic universal for English. Backed (ay0) is not, therefore, the exclusive symbolic province of the Irish. Rather, it can perhaps be employed by any American English speaker displaying toughness: something that is much likelier to be necessary for SES 1 speakers such as Becky and Courtney, regardless of their Italian ethnic affiliation.

In her only interview Courtney devoted a good deal of time to describing South Philadelphian territories. She told me her neighborhood was "okay where I'm at, but two blocks down it's pretty bad." Friends and family from suburban New Jersey, she told me scornfully, were usually scared when they came to visit: "They wanna go home so bad [...] I don't see anything wrong with it though. I guess I'm just a city girl." More than any other student, Courtney talked with authority about the rivalry between particular "corners" and her brother's loyalty to Eighteenth Street, an iconic Italian neighborhood: "He stays there on that corner all day every day." While it seemed clear that it was her brother who generally participated in actual fights, Courtney too was prepared to get involved, because "the worst thing you can do is back down from someone around here." Perceived slights should always be responded to, especially if directed at members of her family.

(10) Courtney: I hate that, when people try to make me look inferior. I hate that. And then the only time I ever f- like I fought other than that was wi- over my brother.

SW: $\quad$ And what was that about? Tell me what happened.

Courtney: Actually it was just something that just- it wasn't even anything that had to do with me. Him and his ex- girlfriend broke up. And uh, she did some really messed up things too, and he was like real upset over it. And I seen her, just, you know - Like my brother is like my world. If there's anybody in my family that- it's him. Like I know he's not like, you know, the greatest person in the world- But he's the same way with me though. Like there's times he's went to like Thirtieth Street to go find someone who just pushed me.

Courtney told me that her parents raised her to defend herself. People in her neighborhood fight all the time, she said, "I mean, to be dead honest, like, some people say they like to fight [...] That's how my brother is. He enjoys it. He'll sit on that corner all day and wait for trouble to fall into his lap. See I'm not like that. I just stay out of everything." But while Courtney might not have participated in corner fights, it was clear that she was proud of both her brother's and her neighborhood's notoriety. 
Becky, by contrast, did not talk about fights, but her best friend was Irish and she spent more time at her friend Erin's house on Second Street than her own, because "her [Erin's] parents don't care." If Becky is making use of backed (ay0), it is perhaps to assert her allegiance to the more casual, unpretentious lifestyle of the Second Streeters whom she admires, whereas for Courtney this vowel is associated with her self-image as a potentially tough street fighter who will defend herself if provoked.

\section{O N C L U S I O N}

Labov (2001) found little evidence of ethnic differentiation in the Philadelphia vocalic system in the 1970s. The present study shows that even when the linguistic effects of ethnic affiliation may not be discernible at the level of the wider speech community, they can be located and explored within specific community subgroups or "communities of practice" (Wenger 1998). Adolescents, potentially, are especially motivated to foreground minor ethnic differences as they negotiate their way through the social marketplace of institutionalized education. Among adolescent girls in South Philadelphia, self-identification as Irish- or ItalianAmerican has subtle effects on their production of (ay0), a vowel not previously recognized as having an ethnic distribution at the community level in Philadelphia. Backer variants of (ay0) were more likely to be produced by Irish girls, or by Italian girls for whom "toughness" was an especially important social meaning. (ay0) indexed "toughness" at both local and supralocal levels. At the level of the school, Irish girls presented a modified form of "toughness" through their reduced participation in the feminine, sexualized rituals of hair and make-up that are performed by Italian adolescent girls, and by their embrace of more stereotypically male behaviors such as burping and fighting. At the level of the local community, the Second Street neighborhood that iconically represents the Irish community in South Philadelphia is associated with the "tough" practices and values of traditional working-class culture, such as physical prowess (sports, fighting), drinking, and loyalty to neighbors. Beyond Philadelphia, (ay0) may also index "toughness" through its association with masculinity and nonconformity. I have argued that an understanding of how ethnicity is constructed at a variety of levels, and within a restricted set of social parameters (age, sex, locality), is necessary to discern how speakers are deploying linguistic features to convey their ethnic affiliation. I believe there is no question that in long-established immigrant communities such as those of the Irish and Italians in South Philadelphia, in which few or no first-language transfer effects are discernible in the majority's use of English, we cannot speak of "ethnolects" or "ethnic varieties." Rather, we must be guided by recent approaches (Eckert 2008b; Benor 2010; Hoffman \& Walker 2010) in which the linguistic construction of ethnicity is viewed as a dynamic process, both from moment-to-moment and from setting-to-setting, as well as across generations. The present study has also supported the notion that ethnicity itself is a fluid 
concept, and that this can be surprisingly evident even in highly culturally and linguistically assimilated communities such as Sacred Heart, in which an individual's claimed ethnicity can encode a linked cluster of social characteristics that go well beyond ancestors' country of origin. In these cases ethnicity is no more and no less than an orientation to a set of behaviors (linguistic, interpersonal, stylistic) that are regularly perceived by others as constituting a meaningful social category, regardless of whether this category is Irish, gay (Podesva 2007), nerd (Bucholtz 1999), hip hop (Cutler 1999), Southern (Allbritten 2011), Catholic (McCafferty 1998), or some other locally or supralocally recognized category. Yet the vowel system of Philadelphia English is clearly not the locus of Irish-Italian linguistic differentiation, as both the present study and earlier studies of Philadelphia have demonstrated. It may be that for these longstanding, co-existing ethnic communities, differentiation in the vowel system requires sharper social differentiation than IrishItalian adolescent rivalry provides. Future work in the South Philadelphia speech community should look beyond vowels, perhaps to consonants (one of my interviewees parodied a typical "princess" Italian mother, using affricated voiceless stops), or perhaps suprasegmental features, as Eckert and her students have fruitfully shown for preadolescent girls (Eckert 2010) and gay male "divas" (Podesva 2007), among other social groups and communities of practice. It is, however, crucial that we continue to relate findings from small, socially bound groups such as the Sacred Heart girls to the wider local speech community (Labov 2011) if we are to understand how "ethnicity" interacts with ongoing language change.

\section{N O T E S}

*This article derives from my doctoral dissertation work, the completion of which could not have occurred without the support of my committee: Gillian Sankoff, William Labov, and Penelope Eckert. I am especially grateful to Penny for encouraging this particular line of enquiry. The participants in the study gave generously of their time and opinions, and are more responsible than anyone for leading me into this exploration of modern American ethnic identity. I must also thank the school administrators who allowed me to spend time with their students. An earlier version of this article was presented at the 35 th New Ways of Analyzing Variation conference in 2006 and at the 30th Penn Linguistics Colloquium in 2007. I am grateful to audience members at both events. Two anonymous reviewers provided very helpful comments. Any errors are my own.

${ }^{1}$ (ay0) is the established notation for this variable in work on the Philadelphia speech community. See, for example, Labov (2001), Conn (2005), and Fruehwald (2008).

${ }^{2}$ I follow the convention established by Labov (e.g. 2001) of representing linguistic variables in parentheses. I also make use of Labov's word-class notation for the representation of American English vocalic variables. See Labov (1994:159-64) for a full explanation.

${ }^{3}$ Minimal, that is, relative to the more salient linguistic and physical differences between these communities and neighboring African-American, Asian, or Latino communities.

${ }^{4}$ The name of the high school and of all participants in the study are pseudonyms.

${ }^{5}$ Henceforward, "South Philadelphia" refers to the City of Philadelphia's Planning Analysis Section B (http://www.phila.gov/cityplanning) which comprises the zipcodes 19145, 19146, 19147, and 19148 and the census tracts within them (13-51). It is a peninsula south of Philadelphia's Center City downtown area, bordered by the Schuykill and Delaware Rivers. Demographic statistics are drawn from the US 


\section{SUZANNE EVANS WAGNER}

Census 2000 for these zipcodes/census tracts. Sacred Heart is located in a central neighborhood comprising census tracts 37-40. Other neighborhoods discussed in this article include the Irish neighborhoods of "Second Street" (tracts 42.01 and 42.02), "Thirtieth Street" (tract 35), Italian middle neighborhoods (tracts 37-40), Packer Park (tracts 45, 47, 48).

${ }^{6} \mathrm{Sex}$ of the participants was controlled to allow a better understanding of linguistic change across the lifespan from a relatively small sample.

${ }^{7}$ For Irish and Irish-English influences on consonants in other varieties of English see, for example, Watson (2007) for Liverpool English and Clarke (2004) for Newfoundland English. For Italian and Italian-American influences on consonants in other varieties of English see, for example, Biondi (1975) for Boston English and Miller (1998) for Philadelphia English.

${ }^{8}$ http://www.fon.hum.uva.nl/praat/

${ }^{9}$ http://www.ling.upenn.edu/ wlabov/Plotnik.html

${ }^{10}$ Vowel formant analysis of F1 and F2 was performed manually on the segmented data, using a 0.7 second averaging window for each nucleus. Information from linear predictive coding (LPC) analysis in the Praat program was used for single point measurement at the major point of inflection of the nucleus (Labov 2001:155-56) or at least 50ms from any consonantal onset. The data were normalized in Plotnik using Nearey's log mean normalization (Labov 2001:159).

11 "Princess" was used pejoratively by Irish girls to describe iconic Italians, who in fact were more frequently referred to by the racial slur "dago." I have chosen not to reproduce this term in my discussion here, although I believe that not all of the Irish girls who used it fully understood its offensiveness. It was never used by Italians in the same way that, for example, "guido" has been reclaimed and redefined by Italian-Americans on the recent US reality show "Jersey Shore." In contrast to the gendered nature of "princess" there were no similarly gendered terms for Irish girls.

${ }^{12}$ In a similar fashion, African-Americans and Asians, who hailed from unfamiliar neighborhoods and had not attended the same grade schools as the white students, could not be fit into the scheme of "where you're from." "Where do they come from?" Melissa asked, addressing noone in particular. "It's as if they're just passing through." Since African-Americans and Asians were not members of the dominant Irish and Italian neighborhood networks, Melissa concluded that they were transitory and thus not placeable in the local social order.

${ }^{13}$ "Stay" means "hang out" in the local vernacular and was always used to refer to an outdoor place where hanging out in groups occurred, such as a corner or a park.

${ }^{14}$ White Anglo-Saxon Protestant

${ }^{15}$ Natalie's mean formant values for (ayV) and (ay0) are both high and mid-back, suggesting that Natalie places tokens of (ayV) in the centralized (ay0) class - an unusual finding.

${ }^{16}$ Labov (2001:203) notes that participants in a self-report test "ruefully acknowledged their own use" of tense (aeh), with comments such as "Would you believe it? that I say it that way?" and "Unfortunately it's South Philly slang, not the best pronunciation" and "I guess [I say it]. I don't like it, it doesn't sound too good."

${ }^{17}$ It is especially associated with black men, but I think the connection is nonetheless evident.

${ }^{18}$ See note 11 .

\section{R E F E R E N C E S}

Adamson, H. D., \& Vera M. Regan (1991). The acquisition of community speech norms by Asian immigrants learning English as a second language: A preliminary study. Studies in Second Language Acquisition 13:1-22.

Allbritten, Rachael (2011). "My accent isn't like out in the woods country... It's just an Alabama drawl”: What makes a Southern accent 'strong'? Paper presented at New Ways of Analyzing Variation (NWAV) 40, Georgetown University, Washington DC, October 27-30.

Benor, Sarah Bunin (2010). Ethnolinguistic repertoire: Shifting the analytic focus in language and ethnicity. Journal of Sociolinguistics 14:159-83. 


\section{WE ACT LIKE GIRLS AND WE DON'T ACT LIKE MEN}

(2012). Echoes of Yiddish in the speech of twenty-first-century American Jews. In Lara Rabinovitch, Shiri Goren, \& Hannah Pressman (eds.), Choosing Yiddish: Studies on Yiddish literature, culture, and history, 319-37. Detroit: Wayne State Press.

Biondi, Lawrence (1975). The Italian-American child: His sociolinguistic acculturation. Washington, DC: Georgetown University Press.

Boberg, Charles (2004). Ethnic patterns in the phonetics of Montreal English. Journal of Sociolinguistics 8:538-68.

Bucholtz, Mary (1999). "Why be normal?": Language and identity practices in a community of nerd girls. Language in Society 28:203-23.

Cameron, Richard (2005). Aging and gendering. Language in Society 34:23-61.

Cheshire, Jenny (2006). Age- and generation-specific use of language. In Ulrich Ammond, Norbert Dittmar, \& Klaus J. Mattheier (eds.), Sociolinguistics: An international handbook of the science of language and society, 1552-63. Berlin: Walter de Gruyter.

, \& Sue Fox (2009). Was/were variation: A perspective from London. Language Variation and Change 21:1-38.

Clarke, Sandra (2004). The legacy of British and Irish English in Newfoundland. In Raymond Hickey (ed.), Legacies of Colonial English: Studies in transported dialects, 242-61. Cambridge: Cambridge University Press.

Conn, Jeffrey (2005). Of "moice" and men: The evolution of a male-led sound change. Philadelphia: University of Pennsylvania dissertation.

- \& Uri Horesh (2002). Assessing the acquisition of dialect variables by migrant adults in Philadelphia: A case study. University of Pennsylvania Working Papers in Linguistics 8(3): 47-57.

Cutler, Cecelia (1999). Yorkville crossing: White teens, hip hop and African American English. Journal of Sociolinguistics 3:428-42.

De Fina, Anna (2007). Code-switching and the construction of ethnic identity in a community of practice. Language in Society 36:371-92.

Dubin, Murray (1996). South Philadelphia: Mummers, memories and the Melrose diner. Philadelphia: Temple University Press.

Dubois, Sylvie, \& Barbara Horvath (1998). Let's tink about dat: Interdental fricatives in Cajun English. Language Variation and Change 10:245-61.

Eckert, Penelope (1989). Jocks and burnouts. New York: Teachers College Press.

(1996). (ay) goes to the city: Exploring the expressive use of variation. In Gregory R. Guy, Crawford Feagin, Deborah Schiffrin, \& John Baugh (eds.), Towards a social science of language, 47-58. Amsterdam: John Benjamins.

- (2000). Linguistic variation as social practice. Malden, MA: Blackwell.

(2005). Variation, convention, and social meaning. Paper presented at the Annual Meeting of the

Linguistic Society of America, 6-9 January, Oakland, California.

- (2008a). Variation and the indexical field. Journal of Sociolinguistics 12:453-76.

(2008b). Where do ethnolects stop? The International Journal of Bilingualism 12:25-42.

(2010). Affect, sound symbolism, and variation. University of Pennsylvania Working Papers in Linguistics 15(2), article 9. Online: http://repository.upenn.edu/pwpl/vol15/iss2/9.

Fought, Carmen (1999). A majority sound change in a minority community: /u/-fronting in Chicano English. Journal of Sociolinguistics 3:5-23.

- (2003). Chicano English in context. New York: Palgrave Macmillan.

, \& John Fought (2002). Prosodic patterns in Chicano English. Paper presented at NWAVE 31, Stanford University, CA.

Fruehwald, Josef (2008). The spread of raising: Opacity, lexicalization and diffusion. University of Pennsylvania Working Papers in Linguistics 14(2):83-92. 
, \& Laurel MacKenzie (2011). New results from hierarchical models of the community grammar. Paper presented at New Ways of Analyzing Variation (NWAV) 40, Georgetown University, Washington, DC, October 27-30.

Gal, Susan, \& Judith T. Irvine (1995). The boundaries of languages and disciplines: How ideologies construct difference. Social Research 64:967-94.

Gordon, Matthew J., \& Jeffrey Heath (1998). Sex, sound symbolism and sociolinguistics. Current Anthropology 39:421-49.

Green, Lisa (2002). African American English: A linguistic introduction. Cambridge: Cambridge University Press.

Hall-Lew, Lauren (2010). Ethnicity and sociolinguistic variation in San Francisco. Language and Linguistics Compass 4:458-72.

Hebdige, Dick (1984). Subculture: The meaning of style. New York: Methuen.

Henderson, Anita (1996). The short 'a' pattern of Philadelphia among African-American speakers. In Miriam Meyerhoff (ed.), (N)WAVES and MEANS: A selection of papers from NWAVE 24. Penn Working Papers in Linguistics 3(1):127-40.

Hershberg, Theodore (ed.) (1981). Philadelphia. New York: Oxford University Press.

Hindle, Donald (1980). The social and structural conditioning of phonetic variation. Philadelphia: University of Pennsylvania dissertation.

Hoffman, Michol, \& James A. Walker (2010). Ethnolects and the city: Ethnic orientation and linguistic variation in Toronto English. Language Variation and Change 22:37-67.

Hughes Jr, Robert, \& Maureen Perry-Jenkins (1996). Social class issues in family life education. Family Relations 45:175-82.

Irvine, Judith T., \& Susan Gal (2000). Language ideology and linguistic differentiation. In Paul Kroskrity (ed.), Regimes of language: Ideologies, polities and identities, 35-84. Santa Fe, NM: School of American Research Press.

Labov, William (1966/2006). The social stratification of English in New York City. Cambridge: Cambridge University Press.

__ Paul Cohen; Clarence Robins; \& John Lewis (1968). A study of the non-standard English of Negro and Puerto Rican speakers in New York City. Final report, Cooperative Research Project 3288. 2 vols. Philadelphia: US Regional Survey.

(1990). The intersection of sex and social class in the course of linguistic change. Language Variation and Change 2:204-54.

- (1994). Principles of linguistic change: Internal factors. Oxford: Blackwell.

(2001). Principles of linguistic change: Social factors. Oxford: Blackwell.

2011. Forty years of sound change in progress. Paper presented at New Ways of Analyzing Variation (NWAV) 40, Georgetown University, Washington, DC, October 27-30.

- Maciej Baranowski, \& Aaron Dinkin (2010). The effect of outliers on the perception of sound change. Language Variation and Change 22:175-90.

Laferriere, Martha (1979). Ethnicity in phonological variation and change. Language 55:603-17.

Lave, Jean, \& Etienne Wenger (1991). Situated learning: Legitimate peripheral participation. Cambridge: Cambridge University Press.

Malan, Karen (1996). Cape Flats English. In Vivian De Klerk (ed.), Focus on South Africa, 125-48. Amsterdam: John Benjamins.

Matthews, Tanya (2006). From category labels to discourse strategies: Girls' categorization practices at Millcreek High. Ithaca, NY: Cornell University dissertation.

McCafferty, Kevin (1998). Shared accents, divided speech community? Change in Northern Ireland English. Language Variation and Change 10:97-121.

Mendoza-Denton, Norma (2008). Homegirls: Language and cultural practice among Latina youth gangs. Oxford: Blackwell.

Meyerhoff, Miriam (1994). Sounds pretty ethnic, eh?: A pragmatic particle in New Zealand English. Language in Society 23:367-388. 


\section{WE ACT LIKE GIRLS AND WE DON'T ACT LIKE MEN}

Miller, Corey (1998). R-lessness in Philadelphia. In Mahendra K. Verma (ed.), Sociolinguistics, language and society, 79-96. New Delhi: Sage.

Milroy, James, \& Milroy, Lesley (1985). Linguistic change, social network and speaker innovation. Journal of Linguistics 21:339-84.

Milroy, Lesley (2002). Social networks. In J. K. Chambers, Peter Trudgill, \& Natalie Schilling-Estes (eds.), The handbook of language variation and change, 549-72. Oxford: Blackwell.

Moore, Emma (2003). Learning style and identity: A sociolinguistic analysis of a Bolton high school. Manchester: University of Manchester dissertation.

Ochs, Elinor (1992). Indexing gender. In Alessandra Duranti \& Charles Goodwin (eds.), Rethinking context: Language as an interactive phenomenon, 335-58. Cambridge: Cambridge University Press.

Podesva, Robert J. (2007). Phonation type as a stylistic variable: The use of falsetto in constructing a persona. Journal of Sociolinguistics 11:478-504.

Poplack, Shana (1978). Dialect acquisition among Puerto-Rican bilinguals. Language in Society 7:89103.

Prichard, Hilary, \& Meredith Tamminga (2012). The impact of higher education on Philadelphia vowels. University of Pennsylvania Working Papers in Linguistics 18(2):87-95.

Rose, Mary (2006). Language, place and identity in later life. Stanford, CA: Stanford University dissertation.

Shuy, Roger; Walt Wolfram; \& William K. Riley (1968). Linguistic correlates of social stratification in Detroit speech. Washington, DC: US Department of Health, Education and Welfare, Office of Education, Bureau of Research.

Silverstein, Michael (2003). Indexical order and the dialectics of sociolinguistic life. Language and Communication 23:193-229.

Stubbe, Maria (1998). Are you listening? Cultural influences on the use of supportive verbal feedback in conversation. Journal of Pragmatics 29:257-89.

Torgersen, Eivind; Costas Gabrielatos; Sebastian Hoffmann; \& Sue Fox (2011). A corpus-based study of pragmatic markers in London English. Corpus Linguistics and Linguistic Theory 7:93-118.

- \& Anita Szakay (2011). A study of rhythm in London: Is syllable-timing a feature of multicultural London English? University of Pennsylvania Working Papers in Linguistics 17(2), article 19. Online: http://repository.upenn.edu/pwpl/vol17/iss2/19.

Trudgill, Peter (1972). Sex, covert prestige and linguistic change in the urban British English context. Language in Society 1:179-95.

Wagner, Suzanne Evans (2008). Language change and stabilization in the transition from adolescence to adulthood. Philadelphia: University of Pennsylvania dissertation.

(2012a). Age grading in sociolinguistic theory. Language and Linguistics Compass 6:371-82.

(2012b). Real time evidence for age grad(ing) in late adolescence. Language Variation and Change 24:179-202.

Watson, Kevin (2007). Liverpool English. Journal of the International Phonetics Association 37:35160.

Wenger, Etienne (1998). Communities of practice: Learning, meaning and identity. Cambridge: Cambridge University Press.

(Received 15 November 2011; revision received 6 August 2012; accepted 28 August 2012; final revision received 13 September 2012) 